\title{
Evaluation of social impact measurement tools and techniques: A systematic review of the literature
}

\author{
Author Name ${ }^{a *}$ and A.N. Author ${ }^{b}$ \\ ${ }^{a}$ Department, University, City, Country \\ ${ }^{b}$ Department, University, City, Country \\ *Corresponding author
}

\begin{abstract}
Purpose: Despite the availability of metrics for measuring social impact, it can be difficult for organisations to select tools that fit their precise needs. To address this challenge, this study conducts a systematic literature review using legitimacy theory as a point of departure. It examines tools that capture three dimensions of sustainability - social, economic and environmental - and firm size.

Design: We searched the top four journal databases in the social sciences from the FT50 review to identify articles published in peer-reviewed journals in the 2009-2019 period, using keywords to conceptualise the construct. For comprehensive assessment, we adopted a method that requires the logic synthesis of concepts and evidence emerging from the literature to address the research aim.

Findings: The results show that most of the articles developed tools or frameworks to measure social impact based on the triple bottom line of sustainability - social, economic and environmental - and firm size. However, there is insufficient evidence of their integration into practice.
\end{abstract}

Research implications: This work contributes to the legitimisation of social enterprises using validated tools and frameworks to develop practical suggestions for social impact measurement.

Originality: Since legitimacy is an important rationale for social impact measurement, this study adds value through the development of a suitability framework. The framework enables social enterprises to identify the most appropriate tool for their purpose and size to establish legitimacy through impact measurement and reporting. 
Keywords: Social impact; Social impact measurement; Social enterprise; Social value

\section{Introduction}

A social enterprise (SE) is a unique mechanism to address poverty (Ghauri et al., 2014), inspire women (Datta and Gailey, 2012), promote comprehensive growth in subsistence marketplaces (Azmat et al., 2015) and create institutional change (Nicholls, 2008). Differing from traditional enterprises, SEs utilise both social and commercial logic to address social, economic and environmental (SEE) issues (Folmer et al., 2018), while prioritising social innovation and societal benefits (Ridley-Duff and Southcombe, 2012). Meanwhile, traditional enterprises' motivation comprises increased revenues and enhanced financial performance (Folmer et al., 2018). Therefore, the SE literature focuses on social change and social impact (SI). As per commercial enterprises, SEs are shaped by mutual principles regarding the control, ownership, financing and engagement with the primary stakeholders: the customers, employees and suppliers (Arthur et al., 2003). However, SEs' complex characteristics lead to difficulties in differentiating them from other models such as philanthropy and charity (Acs et al., 2013), social innovation (Phillips et al., 2015), and corporate social responsibility (Nicolopoulou, 2014). Interestingly, Siqueira et al. (2018) longitudinal study of for-profit SEs and commercial enterprises revealed that for-profit SEs have more leverage stability in terms of capital structure when compared to commercial enterprises of the same size. Whilst this type of knowledge does shift the paradigm of commercial enterprises and SEs, there is clear distinction that SEs are institutions that strive to create social good (Santos, 2012), thus driven by the desire or pressure from external sources to demonstrate SI.

SI represents "the logic of chain results in which organisational inputs and activities lead to a series of outputs, outcomes and ultimately to a set of societal impact" (Ebrahim and Rangan, 2010, p.3). SI is critical to SEs, moulding their social missions, objectives, policies, procedures and operating strategies (Di Domenico et al., 2010; Zahra et al., 2010). 
Unsurprisingly, many studies have examined the measurement of the SI construct (Maas and Liket, 2011; Costa and Pesci, 2016; Rawhouser et al., 2017).

Evidence from recent research reveals external pressure, primarily from funders and policymakers, driving the call for social impact measurement ([SIM] Arena et al., 2015). For instance, the UK government revealed interest in SIM, asserting that "there are real economic and social gains for organisations that use appropriate mechanisms to evaluate their impact and improve their performance" (Department of Trade and Industry [DTI], 2002, p.76). The discourse is also noted in mainland Europe, as investors need to be aware of the positive change produced (Costa and Pesci, 2016). The notion surrounding SIM is accountability and being able to demonstrate dual performance to multiple stakeholders. However, accountability means being answerable to stakeholders with either positive or negative data and information (McLoughlin et al., 2009) or intended and unintended impact (PatersonYoung et al., 2019). There are many approaches to establishing the impact from SEs. Yet, extant research (Costa and Pesci, 2016) calls for better awareness to capture SI information. Some argue that standards for measurement are underdeveloped (Salazar et al., 2012). Therefore, critical understanding of SIM will enable SEs strategic decision-making, organisational learning (Bradford et al., 2020) and attract social investment (Social Impact Investment Taskforce, 2014).

The challenge many organisations face, however, is selecting the most appropriate tool that meet their specific needs. Haski-Leventhal and Mehra (2016) argued that SEs must significantly determine what to measure and report, which leads to a challenge in how they capture this information. Governance issues and support needs also present a unique barrier to capturing SI information (Spear et al., 2009). In the present paper, the authors argue that while existing tools and frameworks can support SEs with SIM, what tools and frameworks can capture the triple bottom line of the SEE objectives remain unclear. Therefore, this study 
presents a critical evaluation of SIM tools and frameworks for SEs. For each paper identified, the focus of assessment (regarding the triple bottom line) and the firm size are examined. The findings are summarised in a conceptual framework that can help SEs to select the most appropriate tool to measure and report their SI. Therefore, this paper seeks to address the following research objectives: i) to conduct a systematic literature review on SIM, ii) to identify the focus of assessment tools regarding the triple bottom line, and iii) to examine the relevance of assessment tools to firm size. The categorisation of firm size in this study are small, medium and large. Although there is no universally accepted definition of firm sizes, that is, small, medium enterprises (OECD, 2004), we adopt characterisation of firm sizes by OECD (2020). Small and medium enterprises are those that employee fewer than 250 people. More specifically, small (10 to 40 employees), medium-sized (50-249 employees) and large enterprises employ 250 or more people (OECD, 2020).

This study begins by introducing the SI and SIM literature, highlighting the unique outcomes and impacts of SE. Then, the research design of the systematic literature review is explained, followed by the conceptual framework derived from the measurement systems reviewed. Finally, a conclusion is presented with aspects for future research.

\section{Social Impact: A critical discussion}

SI is an important construct of social entrepreneurship (Dacin et al., 2010). The construct has been conceptualised in literature using terms such as social return on investment (Hall et al., 2015), social value (Murphy and Coombes, 2009; Di Domenico et al., 2010) social performance (Nicholls, 2008), social returns (Emerson, 2003), social accounting (Nicholls, 2009). In a study exploring value creation, Grieco et al. (2015) used the terms SI and social value interchangeably. These similar, yet different terminologies have contributed to the challenge of understanding SI (Rawhouser et al., 2017). Furthermore, SI has been used in 
diverse contexts of study such as sustainability, education, health care, environmental and poverty (Izzo, 2013).

In this study, SI is used as the terminology to channel the systematic literature review, and the discussion on extant research on SIM. An introspective definition of SI is noted in Burdge and Vanclay (1996, p.59):

The process of assessing or estimating, in advance, the social consequences that are likely to follow from specific policy actions or project development [. . .] Social impacts include all social and cultural consequences to human populations of any public or private actions that alter the ways in which people live, work, play, relate to one another, organize to meet their needs, and generally cope as members of society. Cultural impacts involve changes to the norms, values, and beliefs of individuals that guide and rationalize their cognition of themselves and their society.

The literature recognises the contested nature of SEs and the potential impact of their operations on social objectives (Doherty et al., 2014). SE can tackle SEE issues, whilst operating throughout the economy (Defourny and Nyssens, 2008). An example of a SE addressing both social and environmental issues is Who Gives A Crap, an Australia-based organisation established to address the issues of poor water quality and sanitation, since 2.3 billion people globally have no access to a toilet (World Health Organisation, 2017), representing $40 \%$ of the global population. So, how should such organisation measure their SI? This challenge is exposed in the research on SI within SEs (i.e. Ebrahim et al., 2014). Costa and Pesci (2016) suggested that SEs should define standardised universal assessment units that process comparisons between organisations over time, or to create distinctive assessment units that tailor SIM to the stakeholder's demands.

The ability for SEs to transform communities is noted in Nicholls (2010), Steinerowski and Steinerowska-Streb (2012) and Gordon et al. (2018). Nevertheless, their interventions can be complex, long term and difficult to objectify (Ruebottom, 2011). As highlighted by the Organisation for Economic Co-operation and Development ([OECD], 
2010), assessing SI is a challenging task due to the complexities of identifying quantitative and qualitative tools for reporting information to stakeholders. This view is echoed in literature (e.g. Cordery and Sinclair, 2013; MacIndoe and Barman, 2013), with regional institutions also researching this construct; for example, the Institute for Social Entrepreneurship in Asia and the EMES European Research Network have researched the evaluation of SI in SEs. The current debate has shifted to the legitimacy of these organisations (Bradford et al., 2020), which ultimately raises questions regarding their sustainability and level of influence on the broader structural conditions (Gordon et al., 2018).

Despite the discourse concerning the contributions of SE being non-nuanced, this can be noted in the UK Government's strategy for SE (DTI, 2002, p.24), which identified a number of objectives to which they could contribute: "helping to drive up productivity and competitiveness; contributing to socially inclusive wealth creation; enabling individuals and communities to work towards regenerating their local neighbourhoods; showing new ways to deliver and reform public services; and helping to develop an inclusive society and active citizenship". Notwithstanding the growing literature on SI in SEs, such organisations must confront the challenge of comprehending the specific reporting requirements of funders (Gordon et al., 2018), how SI is measured (Defourny and Nyssens, 2008), and selecting the optimum tool or framework for SI measurement (Grieco et al., 2015; Costa and Pesci, 2016).

\section{Approaches to Social Impact Measurement}

Over recent years, UK SEs have encountered new auditing standards introduced through social policies that emphasise SI (Arvidson and Lyon, 2014). The standards have been established in policy documents and legislation such as the Department of Health's (2011) Open Public Services White Paper and the Public Services (Social Value) Act (HM 
Government, 2012), which are linked to accountability, competition for resources, and legitimacy (Pritchard et al., 2012). The emphasis on SI is noticeable in the taskforce set-up by the UK government and even in Europe. For instance, in 2013, the Social Impact Investment Taskforce was initiated to catalyse the SI investment market. In addition, to develop general guidelines for SIM practice to be used by social investors globally (GOV.UK, 2020).

From a global perspective, there is a renewed opportunity for organisations to capture their contributions to the United Nations Sustainable Development Goals (UN SDGs) agenda. Such opportunity is explored in the joint paper by Business Call to Action (BCtA) and Global Reporting Initiative (2016) report, which examined how private sector organisations measure their contributions to the SDGs through impact measurement and sustainability reporting. Furthermore, the OECD (2015) report on SI investment emphasis on evidence base through international collaboration, standardised framework and evaluation of policies that support impact measurement. This development adds to the second objective of this study on identifying the most appropriate SIM tool to the triple bottom line.

SIM is defined as the process of defining, monitoring and employing measures to demonstrate benefits created for the target beneficiaries and societies through evidence of social outcomes and/or impacts (McLoughlin et al., 2009). Arvidson and Lyon (2014) argued that the pressure on SEs to conduct robust SI and reporting originates from different stakeholder groups, while increasing pressure from funders and policy-makers (Nicholls, 2009; Desa and Basu, 2013; Ebrahim and Rangan, 2014; Hadad and Găucă, 2014; Arena et al., 2015; Costa and Pesci, 2016) represent key drivers for SIM. However, such stakeholders' expectations for what and how to measure can differ, whereby the differences in measurement expectations may cause uncertainty in terms of selecting the most appropriate tool or framework. With such heterogeneity, the measurement includes positive and negative 
effects, intended and unintended effects, and both the short- and long-term consequences (Wainwright, 2002). For example, if a SE is addressing food poverty in a local region, they may surprisingly tackle drug misuse or petty crime.

Due to the differing nature of SEs objectives and rationale for measuring SI, there is no purpose in a 'one-size-fits-all' approach. Instead, SEs should measure and report critical aspects of their social objectives to relevant stakeholders (Costa and Pesci, 2016). However, the lack of theorisation and conceptual framing on evaluation means that developing a robust understanding of SIM is vital (Hall, 2014). Bagnoli and Megali (2011) found economic and financial performance, and institutional legitimacy to be the rationales for SIM. Meanwhile, Haski-Leventhal and Mehra's (2016) study on SIM in Australia and India revealed that SEs utilise formal impact assessments for performance-monitoring purposes, although several minor discrepancies were identified regarding the data-capture process. Other studies (Arvidson and Lyon, 2014; Pathak and Dattani, 2014) found resource acquisition, mission reinforcement and general stakeholder accountability to be the rationales. Based on interviews with individuals working on SIM, Arvidson and Lyon (2014) highlighted that most non-profit SEs were willing to comply with external resource providers' requests for SIM. However, they also showed resistance through their discretion in determining how and what to measure, and what to report.

SEs employ SI for learning and promotional purposes, and as a means of exerting control over the environment (Arvidson and Lyon, 2014). If SEs are to achieve a sustainable impact and continue to grow, they must demonstrate their usefulness through SI (McLoughlin et al., 2009). SIM is important for creating organisational legitimacy, including symbolic legitimacy and trust (Luke et al., 2013), therefore providing SEs with an optimum framework to select the most suitable tool or framework to improve their SI and SIM strategies, while facilitating the learning process (Connolly and Kelly, 2011; Arvidson and Lyon, 2014). 
Pressure for SIM has driven an increase in approaches (Florman et al., 2016). For instance, the New Economics Foundation ([NEF], 2009) compiled a number of tools and frameworks for SIM (see Table I): Social Return on Investment (SROI), Social Accounting and Auditing (SAA), the Social Enterprise Balance Scorecard (SEBC), the Social IMPact Measurement for Local Economies (SIMPLE), the Third Sector Performance Dashboard (TSPD), Quality First (QF), Prove It (PI), Local Multiplier 3 (LM3), the Practical Quality Assurance System for Small Organisations (PQASSO), the ISO 9001:2008 standard, and the Investors in People Standard (IiPS). Furthermore, there is the Volunteering Impact Assessment Toolkit (VIAT), the Big Picture, the AA1000 Assurance Standard (AA1000 AS), Eco-mapping, the Development Trusts Association's (DTA) Fit for Purpose, the EU's Eco-Management and Audit Scheme (EMAS), the Global Reporting Initiative (GRI) guidelines, the European Foundation for Quality Management's (EFQM) Excellence Model, and the Co-operative Environmental and Social Performance Indicators (CESPIs). Other tools such as the Theory of Change ([ToC] Weiss, 1995) and Logic Model ([LM] Suchman, 1967) are drawn from Social Impact Scotland (2017). Despite this plethora of methodologies, SEs face the complexity of identifying the most appropriate tool to assess their interventions.

Clifford et al. (2013) found that although SEs recognise the tools available, a common issue is the diverse data requirements of the different stakeholder groups. Gordon et al. (2018) argued that quantitative data provides limited understanding of how SEs' policies affect individuals and community health. SIM signals the quality and legitimacy of SEs through performance and impact evaluation (Luke et al., 2013).

Table I: Examples of social impact tools

\begin{tabular}{lll}
\hline Tool & Area of focus & Developed by \\
\hline AA1000 AS & SEE & Social Accounting and Audit \\
\hline CESPIs & $\begin{array}{l}\text { Environmental and social } \\
\text { performance }\end{array}$ & Co-operatives UK \\
\hline
\end{tabular}




\begin{tabular}{|c|c|c|}
\hline DTA & Development & Development Trusts Association \\
\hline Eco-mapping & Environmental & Heinz-Werner Engel \\
\hline EMAS & Environmental & $\begin{array}{l}\text { EMAS \& The International } \\
\text { Network for Environmental } \\
\text { Management }\end{array}$ \\
\hline EFQM & $\begin{array}{l}\text { Quality, performance and } \\
\text { development }\end{array}$ & $\begin{array}{l}\text { The European Foundation for } \\
\text { Quality Management }\end{array}$ \\
\hline GRI Guidelines & $\begin{array}{l}\text { Economic, environmental and } \\
\text { social }\end{array}$ & Global Reporting Initiative \\
\hline IiPS & Organisation performance & UK National Training Task Force \\
\hline ISO 9001 & Quality management & $\begin{array}{l}\text { International Organisation } \\
\text { Standard }\end{array}$ \\
\hline LM & $\begin{array}{l}\text { Policy development or programme } \\
\text { strategy }\end{array}$ & $\begin{array}{l}\text { Carol Weiss, Joseph Wholey \& } \\
\text { others }\end{array}$ \\
\hline LM3 & Local economy & NEF \\
\hline PQASSO & Quality assurance & Charities Evaluation Services \\
\hline Prove It & Regeneration & $\begin{array}{l}\text { NEF } \\
\text { Groundwork UK } \\
\text { Barclays Bank PLC }\end{array}$ \\
\hline Quality First & Organisational performance & $\begin{array}{l}\text { Tony Farley \& Birmingham } \\
\text { Voluntary Service Council }\end{array}$ \\
\hline SAA & SEE & NEF, John Pearce \& Simon Zadek \\
\hline SEBC & SEE & Robert Kaplan \& David Norton \\
\hline SIMPLE & Social impact & $\begin{array}{l}\text { Social Enterprise London } \\
\text { University of Brighton }\end{array}$ \\
\hline SROI & SEE & $\begin{array}{l}\text { Roberts Enterprise Development } \\
\text { Fund }\end{array}$ \\
\hline ToC & Social and economic & Aspen Institute \\
\hline The Big Picture & Organisational performance & $\begin{array}{l}\text { Scottish Council for Voluntary } \\
\text { Organisations }\end{array}$ \\
\hline TSPD & Organisational performance & Social Firms UK \\
\hline VIAT & Organisational change & $\begin{array}{l}\text { Institute for Volunteering } \\
\text { Research }\end{array}$ \\
\hline
\end{tabular}

\section{Legitimacy Theory: Rationale for measuring social impact}

There is increasing demand for SE transparency, comparability and legitimacy by external stakeholders, while internal stakeholders require feedback, guidance and information on 
future resource allocation (Arvidson et al., 2010; Luke et al., 2013). Nicholls (2009) highlighted a 'top-down' movement toward adopting business models and reporting practices in the social sector that assumes these enhance stakeholder accountability, improve transparency, and therefore offer enhanced performance legitimacy. There is also a 'bottomup' trend toward facilitating greater stakeholder engagement in designing the reporting practices that affect them. However, determining what should be measured and how this should be conducted is challenging. Numerous approaches have been developed to evaluate and measure SI (Zappalà and Lyons, 2009). The adoption of a tool or framework is of specific interest to SEs because it supports internal decision-making and addresses the need for accountability to stakeholders (Crucke and Decramer, 2016). Yet, most of the literature on the subject matter in the social sector (including SEs) is under-theorised and requires conceptual framing (Ebrahim and Rangan, 2014). Nonetheless, SEs need to measure their SI systematically and ensure accountability (Syrjä et al., 2015).

Since SEs face a fundamental challenge regarding their evidence and reporting standards, the legitimacy of their existence is questioned. Dart (2004) argued that the authenticity of SEs is not derived from any rational assessment of results, but rather from the society's wider fixation with business ideology and the belief that the 'market knows best'. Legitimacy theory "is a generalised perception or assumption that the actions of an entity are desirable, proper or appropriate within some socially constructed system of norms, values, beliefs and definitions" (Suchman, 1995, p.574). The concept of the social contract is critical to legitimacy theory (Patten, 1992), with Shocker and Sethi (1974) asserting that social institutions operate in society through social contracts to deliver socially desirable goals. Therefore, SEs must utilise a variety of tools and frameworks to evaluate SI and communicate legitimacy (Luke, 2016). 
Suddaby et al.'s (2016) analysis of legitimacy theory presents three dimensions: i) legitimacy as a property, whereby legitimacy is theorised as a thing (i.e. property, a capacity or a resource); ii) legitimacy as a process, which concerns the legitimation of the institution as opposed to 'legitimacy' itself; and iii) legitimacy as perception, where it is considered to be a form of socio-cognition or evaluation. SIM reporting is a communication vehicle assisting SEs to increase transparency and legitimacy to bridge information asymmetry by sharing information on financial performance and social achievements (Adams and Simnett, 2011). This study adopts the view that legitimacy is both a process and a perception. In the view of the former, SEs interact with their stakeholders to measure the SI created (i.e. any stakeholder group: internal (employees) or external (public)). Depending on the interaction, the legitimacy of the organisation can be signalled. Therefore, embedding indicators, measuring and reporting appropriate information is vital. However, many SEs still struggle due to their limited access to measurement tools, knowledge, time and other required resources (Luke et al., 2013).

On the other hand, legitimacy as a perception is an evaluation tool and framework adopted to measure the impact created, with both perspectives supporting the objectives of this study. Any effort to propose an assessment tool to better understand how different SEs operate and perform would be a favourable development (OECD, 2015). The framework developed in this paper will assist SEs to identify the most appropriate tool or framework to meet their social mission and help to avoid risks or the repetition of past mistakes (Asmalouskij et al., 2019). In the context of this paper, the quality of the SE refers to its ability to create impact and report on it. One way of signalling the quality and legitimacy of SEs is through the evaluation of performance regarding the outcomes and impacts (Luke et al., 2013).

\section{Methodology}


In conducting a systematic literature review on SIM and tools, we adopted the method promoted by Nolan and Garavan (2016), which requires a logic synthesis of concepts and evidence emerging from the literature to address the research aim. We targeted four key databases that provide access to management and social science journals to identify articles published over the past decade (2009-2019): Emerald Insight, Science Direct, ProQuest, and EBSCO Host. Given the varied terminology employed to study the construct of SI, we used the following keywords in our search to conceptualise the construct: 'social impact measurement', 'social impact evaluation tools', 'social impact methods', 'impact measurement', 'triple bottom line', and 'social value'. Figure 1 visually describes the systematic review process.

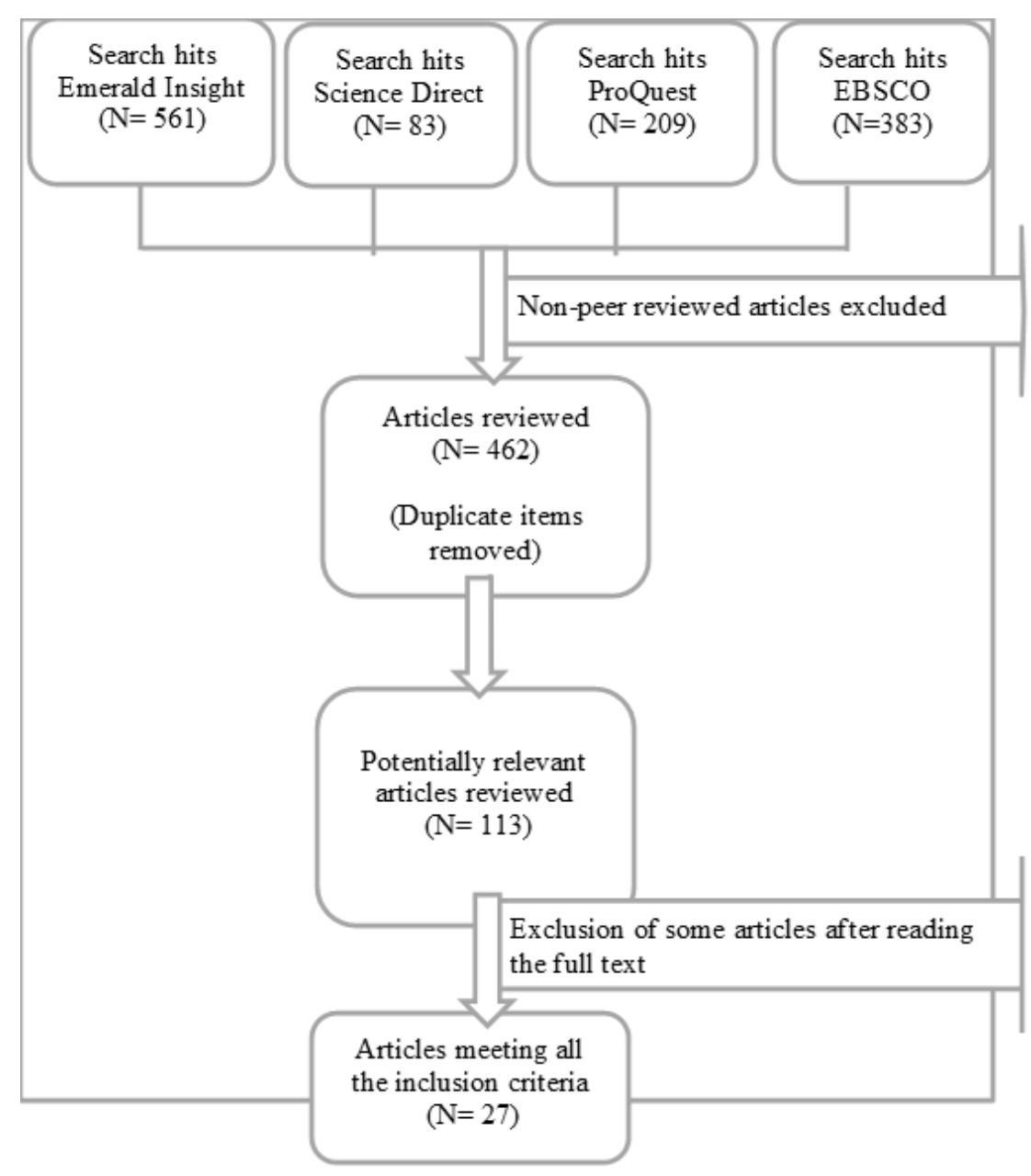

Figure 1. The systematic review process 
To be eligible for inclusion, the articles must have been published in a scholarly journal, written in the English language, and published between January 2009 and January 2019. The initial search yielded 1,236 articles, which we filtered to exclude conference papers, books, monographs and working papers. Using these criteria, we identified 462 articles for further consideration. We removed all duplicate articles and ensured that nonresearch-based papers such as government or institutional reports were excluded, which left 133 articles for further review. To confirm that the articles were pertinent to the research aim, we read the abstract first and then thoroughly reviewed the findings to ensure they investigated SI or discussed SI tools or frameworks. This process resulted in 27 articles considered to be the most relevant for analysis with reference to the research aim.

\subsection{Data Abstraction, Coding and Synthesis}

We read all 27 articles, followed by a thematic coding process. The matrix approach advocated by Cho and Egan (2009) was adopted for the initial evaluation of these articles in a structured manner, and a categorisation table was created (see Table IV) that classified the articles regarding the authors' name and publication year, the research purpose, the methodology and method, and specific features of the SEs (i.e. the focus of assessment and firm size). We utilised these data to provide descriptive information regarding the selected articles before continuing the thematic analysis process. Using the framework conceptualised in Table IV, we identified themes that characterise the scope, dimension, and relevance of the SIM tools, with the results of our analysis presented in section 6 .

\subsection{Descriptive Results of the Review}

This review includes articles published in seventeen different journals, with the more prominent journals being Social Enterprise and VOLUNTAS (International Journal of 
Voluntary and Non-profit Organisations), which published five and three articles, respectively. Meanwhile, two articles each were published in the Non-profit and Voluntary Sector Quarterly and the Journal of Social Entrepreneurship, whereas only one relevant article was found in each of the remaining thirteen journals. This suggests that approaches for measuring SI could be relevant to diverse subject areas such as accounting, marketing and multidisciplinary studies other than social entrepreneurship and non-profit enterprises. Regarding the research methodologies employed in the selected articles, we noticed the predominance of conceptual studies (ten articles) such as the literature review and systematic review, while other articles were based on theoretical assumptions rather than empirical analysis. Whereas qualitative methods including case study, interviews and action research (utilised in three, two and one articles, respectively) were more prevalent than quantitative approaches such as survey (utilised in four articles). This suggests that the tools for measuring SI can be explored further through qualitative focus; for example, to determine the impacts and effectiveness. Table II presents a statistical summary of the main characteristics of our review, while Table III presents those studies that developed models.

Table II. Summary of the descriptive results

\begin{tabular}{|c|c|c|c|}
\hline Year & No. & Journal & No. \\
\hline 2019 & 2 & Social Enterprise Journal & 5 \\
\hline 2018 & 1 & $\begin{array}{l}\text { VOLUNTAS: International Journal of Voluntary and } \\
\text { Nonprofit Organisations }\end{array}$ & 3 \\
\hline 2017 & 2 & Journal of Social Entrepreneurship & 2 \\
\hline 2016 & 4 & Non-profit and Voluntary Sector Quarterly & 2 \\
\hline 2015 & 3 & Academy of Entrepreneurship Journal & 1 \\
\hline 2014 & 5 & Accounting, Organizations and Society & 1 \\
\hline 2013 & 1 & Australian Journal of Public Administration & 1 \\
\hline
\end{tabular}




$\begin{array}{ll}\text { Method } & \text { No. } \\ \text { Conceptual } & 10 \\ \begin{array}{l}\text { Systematic } \\ \text { review }\end{array} & 6 \\ \text { Survey } & 4 \\ \text { Case study } & 3 \\ \begin{array}{l}\text { Interview } \\ \text { Action research }\end{array} & 1 \\ \begin{array}{l}\text { Participatory } \\ \text { analysis }\end{array} & 1\end{array}$

Table III. Studies that developed models

\begin{tabular}{ll}
\hline Article & Model developed \\
\hline Arena et al. (2015) & Performance measurement system model \\
\hline Bagnoli and Megali (2011) & Multi-dimensional controlling model \\
\hline Ebrahim and Rangan (2014) & Social performance framework \\
\hline Edwards et al. (2015) & Structural equation modelling of social impact \\
\hline Hadad and Găucă (2014) & Sustainability, added value and scalability \\
\hline Lane and Casile (2011) & Economic survival framework \\
\hline Mouchamps (2014) & Analytical framework \\
\hline Nicholls (2009) & Blended value accounting spectrum \\
\hline Polonsky and Grau (2011) & Four-category typology of alternative approaches \\
\hline White (2018) & Framework for capability and integrative approaches \\
\hline
\end{tabular}




\section{Findings and Discussion}

The findings from the systematic literature review are presented in Table IV, and then discussed in sections 6.1 and 6.2, consistent with the research objectives.

Table IV. Findings from the systematic literature review on social impact

\begin{tabular}{|c|c|c|c|c|}
\hline Authors & Research purpose & $\begin{array}{l}\text { Methodology/ } \\
\text { method }\end{array}$ & $\begin{array}{c}\text { Specific features of } \\
\text { SE }\end{array}$ & \\
\hline & & & Focus of assessment & $\begin{array}{l}\text { Firm size } \\
\text { mentioned }\end{array}$ \\
\hline Arena et al. (2015) & $\begin{array}{l}\text { To develop an approach } \\
\text { applicable to/by SEs to } \\
\text { measure SEE results. }\end{array}$ & $\begin{array}{l}\text { Qualitative } \\
\text { Case study }\end{array}$ & $\mathrm{EC}, \mathrm{SC}, \mathrm{EI}$ & $\mathrm{SM}$ \\
\hline $\begin{array}{l}\text { Arvidson and Lyon } \\
\text { (2014) }\end{array}$ & $\begin{array}{l}\text { To examine the } \\
\text { participation and } \\
\text { behaviour of non-profit } \\
\text { organisations regarding } \\
\text { the request for SI } \\
\text { evaluation. }\end{array}$ & $\begin{array}{l}\text { Qualitative } \\
\text { Interviews }\end{array}$ & $\mathrm{EC}, \mathrm{SC}$ & SML \\
\hline $\begin{array}{l}\text { Bagnoli and Megali } \\
\text { (2011) }\end{array}$ & $\begin{array}{l}\text { To analyse three } \\
\text { reference fields of } \\
\text { management to provide a } \\
\text { multi-dimensional } \\
\text { controlling framework to } \\
\text { manage SEs. }\end{array}$ & Quantitative & $\mathrm{EC}, \mathrm{SC}, \mathrm{EI}$ & $\mathrm{SM}$ \\
\hline $\begin{array}{l}\text { Barraket and } \\
\text { Yousefpour (2013) }\end{array}$ & $\begin{array}{l}\text { To investigate small SEs } \\
\text { in Australia. }\end{array}$ & $\begin{array}{l}\text { Action } \\
\text { research }\end{array}$ & $\mathrm{SC}, \mathrm{EI}$ & SM \\
\hline Belluci et al. (2019) & $\begin{array}{l}\text { To assess the } \\
\text { effectiveness of SROI } \\
\text { used by non-profit } \\
\text { organisations and SEs } \\
\text { that supports family- } \\
\text { centred care. }\end{array}$ & $\begin{array}{l}\text { Participatory } \\
\text { analysis }\end{array}$ & $\mathrm{EC}, \mathrm{SC}, \mathrm{EI}$ & SML \\
\hline $\begin{array}{l}\text { Clark and Brennan } \\
\text { (2012) }\end{array}$ & $\begin{array}{l}\text { To investigate how SI is } \\
\text { measured. }\end{array}$ & Quantitative & $\mathrm{EC}, \mathrm{SC}, \mathrm{EI}$ & SML \\
\hline $\begin{array}{l}\text { Ebrahim and } \\
\text { Rangan } \\
(2014)\end{array}$ & $\begin{array}{l}\text { To develop a } \\
\text { performance assessment } \\
\text { framework premised on } \\
\text { an organisation's } \\
\text { operational mission, } \\
\text { scale, and scope. }\end{array}$ & Case analysis & $\mathrm{EC}, \mathrm{SC}, \mathrm{EI}$ & SML \\
\hline
\end{tabular}




\begin{tabular}{|c|c|c|c|c|}
\hline Edwards et al. (2015) & $\begin{array}{l}\text { To develop a new } \\
\text { conceptualisation of SI } \\
\text { beyond small evaluation } \\
\text { outcomes. }\end{array}$ & $\begin{array}{l}\text { Focus groups } \\
\text { Interviews }\end{array}$ & $\mathrm{EC}, \mathrm{SC}, \mathrm{EI}$ & $\mathrm{L}$ \\
\hline Esteves et al. (2012) & $\begin{array}{l}\text { To conduct an SIA SWOT } \\
\text { analysis. }\end{array}$ & Conceptual & $\mathrm{EC}, \mathrm{SC}, \mathrm{EI}$ & NS \\
\hline $\begin{array}{l}\text { Gibbon and Dey } \\
\text { (2011) }\end{array}$ & $\begin{array}{l}\text { To present a critical } \\
\text { review of SAA and SROI. }\end{array}$ & Conceptual & $\mathrm{EC}, \mathrm{SC}, \mathrm{EI}$ & SML \\
\hline Grieco et al. (2015) & $\begin{array}{l}\text { To develop hierarchical } \\
\text { cluster analysis to help } \\
\text { social entrepreneurs } \\
\text { choose the optimum } \\
\text { model for their } \\
\text { organisational needs. }\end{array}$ & $\begin{array}{l}\text { Systematic } \\
\text { review } \\
\text { Hierarchical } \\
\text { cluster analysis }\end{array}$ & $\mathrm{EC}, \mathrm{SC}, \mathrm{EI}$ & SML \\
\hline $\begin{array}{l}\text { Hadad and Gauca } \\
(2014)\end{array}$ & $\begin{array}{l}\text { To connect social change, } \\
\text { social problems and social } \\
\text { entrepreneurship to SIM } \\
\text { approaches. }\end{array}$ & Conceptual & $\mathrm{EC}, \mathrm{SC}, \mathrm{EI}$ & $\mathrm{SM}$ \\
\hline Irene et al. (2016) & $\begin{array}{l}\text { To review contrasting } \\
\text { accounting frameworks, } \\
\text { including those applicable } \\
\text { to the social business } \\
\text { sector. }\end{array}$ & $\begin{array}{l}\text { Systematic } \\
\text { review }\end{array}$ & $\mathrm{EC}, \mathrm{SC}, \mathrm{El}$ & NS \\
\hline $\begin{array}{l}\text { Kato et al. } \\
\text { (2017) }\end{array}$ & $\begin{array}{l}\text { To present a theoretical } \\
\text { framework and measures } \\
\text { and instruments for } \\
\text { evaluating social change. }\end{array}$ & $\begin{array}{l}\text { Secondary data } \\
\text { Review papers }\end{array}$ & $\mathrm{EC}, \mathrm{SC}, \mathrm{El}$ & SML \\
\hline Klemela (2016) & $\begin{array}{l}\text { To demonstrate how the } \\
\text { SROI method legitimises } \\
\text { organisations/projects } \\
\text { with multiple discursive } \\
\text { options besides the SROI } \\
\text { ratio. }\end{array}$ & SROI reports & $\mathrm{EC}, \mathrm{SC}, \mathrm{EI}$ & NS \\
\hline $\begin{array}{l}\text { Lane and Casile } \\
\text { (2011) }\end{array}$ & $\begin{array}{l}\text { To assist social } \\
\text { entrepreneurs and } \\
\text { academics, apply current } \\
\text { knowledge and gain } \\
\text { feedback about the } \\
\text { success of social } \\
\text { activities. }\end{array}$ & $\begin{array}{l}\text { Theoretical } \\
\text { and empirical } \\
\text { review }\end{array}$ & $\mathrm{EC}, \mathrm{SC}, \mathrm{El}$ & NS \\
\hline $\begin{array}{l}\text { Maas and Grieco } \\
(2017)\end{array}$ & $\begin{array}{l}\text { To examine whether SEs } \\
\text { are assessing and checking } \\
\text { their SI. }\end{array}$ & $\begin{array}{l}\text { Quantitative } \\
\text { Global } \\
\text { entrepreneursh } \\
\text { ip } \\
\text { Monitoring } \\
\text { data }\end{array}$ & $\mathrm{EC}, \mathrm{SC}, \mathrm{EI}$ & NS \\
\hline $\begin{array}{l}\text { Maas and Liket } \\
\text { (2011) }\end{array}$ & $\begin{array}{l}\text { To test whether } \\
\text { organisations are strategic } \\
\text { in their philanthropy. }\end{array}$ & $\begin{array}{l}\text { Longitudinal } \\
\text { cross-sectional } \\
\text { data }\end{array}$ & $\mathrm{EC}, \mathrm{SC}, \mathrm{EI}$ & SML \\
\hline
\end{tabular}




\begin{tabular}{|c|c|c|c|c|}
\hline & & $\begin{array}{l}\text { Cross-national } \\
\text { data }\end{array}$ & & \\
\hline $\begin{array}{l}\text { McLoughlin et al. } \\
\text { (2009) }\end{array}$ & $\begin{array}{l}\text { To develop a } \\
\text { comprehensive and } \\
\text { vigorous methodology for } \\
\text { SIM of SEs to enable } \\
\text { practical bases for } \\
\text { training. }\end{array}$ & $\begin{array}{l}\text { SIMPLE } \\
\text { impact }\end{array}$ & $\mathrm{EC}, \mathrm{SC}, \mathrm{EI}$ & SML \\
\hline Migliavacca (2016) & $\begin{array}{l}\text { To recap existing reviews } \\
\text { of measures and } \\
\text { methodologies for } \\
\text { evaluating SI. }\end{array}$ & $\begin{array}{l}\text { Systematic } \\
\text { review }\end{array}$ & $\mathrm{EC}, \mathrm{SC}, \mathrm{EI}$ & SML \\
\hline Mouchamps (2014) & $\begin{array}{l}\text { To examine SEs' } \\
\text { consistency in using } \\
\text { performance tools. }\end{array}$ & $\begin{array}{l}\text { Systematic } \\
\text { review } \\
\text { Construction } \\
\text { of analytical } \\
\text { framework }\end{array}$ & $\mathrm{EC}, \mathrm{SC}, \mathrm{El}$ & NS \\
\hline $\begin{array}{l}\text { Narangajavana et al. } \\
\text { (2016) }\end{array}$ & $\begin{array}{l}\text { To analyse, define and } \\
\text { examine the relationship } \\
\text { between social } \\
\text { entrepreneurship and the } \\
\text { generation of social value. }\end{array}$ & Conceptual & $\mathrm{EC}, \mathrm{SC}, \mathrm{EI}$ & SM \\
\hline Nicholls (2009) & $\begin{array}{l}\text { To conduct exploratory } \\
\text { analysis of the growing } \\
\text { reporting practices } \\
\text { adopted by social } \\
\text { entrepreneurs. }\end{array}$ & Case studies & $\mathrm{EC}, \mathrm{SC}, \mathrm{EI}$ & NS \\
\hline $\begin{array}{l}\text { Pathak and Dattani } \\
\text { (2014) }\end{array}$ & $\begin{array}{l}\text { To explore three technical } \\
\text { challenges and } \\
\text { misconceptions of } \\
\text { measuring SROI. }\end{array}$ & Conceptual & $\mathrm{EC}, \mathrm{SC}, \mathrm{EI}$ & SML \\
\hline $\begin{array}{l}\text { Polonsky and Grau } \\
\text { (2011) }\end{array}$ & $\begin{array}{l}\text { To develop a four- } \\
\text { category typology of } \\
\text { alternative approaches to } \\
\text { help charities determine } \\
\text { their optimum approach. }\end{array}$ & Conceptual & $\mathrm{SC}, \mathrm{El}$ & NS \\
\hline $\begin{array}{l}\text { Rawhouser et al. } \\
\text { (2019) }\end{array}$ & $\begin{array}{l}\text { To examine, conceptually } \\
\text { or empirically, SI } \\
\text { measurement via } \\
\text { systematic literature } \\
\text { review. }\end{array}$ & $\begin{array}{l}\text { Systematic } \\
\text { review }\end{array}$ & $\mathrm{EC}, \mathrm{SC}, \mathrm{EI}$ & SL \\
\hline White (2018) & $\begin{array}{l}\text { To develop a framework } \\
\text { for measuring the impact } \\
\text { of social purpose } \\
\text { organisations. }\end{array}$ & $\begin{array}{l}\text { Qualitative } \\
\text { Case study }\end{array}$ & $\mathrm{SC}$ & SML \\
\hline
\end{tabular}

Note: $\mathrm{EC}=$ environmental contribution, $\mathrm{EI}=$ economic impact, $\mathrm{L}=$ large, $\mathrm{NS}=$ not specified, $\mathrm{S}=$ small, $\mathrm{SC}=$ social contribution, $\mathrm{SM}=$ small and medium, $\mathrm{SML}=$ small, medium and large 


\subsection{Focus of Assessment Tools Regarding the Triple Bottom Line}

Most studies developed tools appropriate for SEs to assess the impact of their organisations on the triple bottom line of sustainability, namely the SEE objectives (i.e. Nicholls, 2009; Maas and Liket, 2011; Esteves et al., 2012; Mouchamps, 2014; Arena et al., 2015; Grieco et al., 2015; Migliavacca, 2016; Kato et al., 2017); for example, Nicholls (2009) conducted an exploratory study of how social entrepreneurs utilise reporting practices to address the SEE objectives in their organisations. Drawing on the multiple theoretical perspectives of positivism, critical theory and interpretivism, Nicholls (2009) proposed the concept of 'blended value accounting' as a new theoretical approach to guide the reporting, disclosure, and auditing in social entities. However, his study was based on theoretical explanations drawn from UK cases, which might have limited global significance. Nonetheless, blended reporting and disclosure could enable SEs establish legitimacy to different stakeholders, and prevent challenge to their legitimacy (Luke, 2016).

On the other hand, Esteves et al. (2012) developed a framework that highlights integrated environmental life-cycle assessment and life-cycle costing into the evaluation of SIs. Their framework, which was coined the Social Impact Management Plan, contributes to the achievement of the triple bottom line of sustainability. Furthermore, in attempting to measure value creation in SEs, Grieco et al. (2015) conducted a hierarchical cluster analysis of existing SI assessment models in the literature. While the authors offered a classification matrix that can help managers in the non-profit and voluntary sector to select those methods that best meet the organisation's specific needs regarding the assessment of SI, their argument does not clarify which model would be most suited for organisations with different sustainability focus. In other words, there was limited information about the impact typology regarding the SEE aspects. 
As per Grieco et al. (2015), the SI evaluation approach developed by Arena et al. (2015) seeks to address SEE performance, although not all these aspects are fully addressed in their performance dimension indicators. Rather, they proposed a stepwise method that social entrepreneurs could follow in measuring performance by highlighting the value-added regarding resource, product and results. Although their framework depicts the diversity in SE nature, focus and context of operations, the emphasis is placed on the importance of linking corporate performance dimensions with different types of stakeholders. Hadad and Găucă's (2014) approach to measuring SI focuses on three elements: sustainability, added value and scalability. And while the 'added value' element of their framework reflects, to a certain extent, the broader SEE and political factors relevant to SEs, the suitability and managerial implications remain uncertain; for example, in practice, a definitive distinction is necessary for measuring a wide range of social and environmental impacts, yet the study does not offer examples of questions that SEs can ask employees or stakeholders to identify their environmental impact.

Only a small number of tools developed in the literature do not focus on measuring the three dimensions of sustainability by SEs (e.g. McLoughlin et al., 2009; Polonsky and Grau, 2011; Barraket and Yousefpour, 2013; Arvidson and Lyon, 2014; White, 2018). In a search for an integrative system to demonstrate the value of social purpose organisations, White (2018) developed a framework for measuring the impact of social endeavours, whereas McLoughlin et al. (2009) proposed the SIMPLE model for the same purpose. However, White's (2018) framework was built upon Sen's (1993) capability approach, and thus has limited practical implications, unlike the SIMPLE model that establishes five clear steps that managers can follow to assess, identify, prioritise and improve SI. Polonsky and Grau (2011) adopted a similar stepwise approach to develop a four-category typology of alternative tools for managers of charity organisations to determine which perspective would be most suited to 
their specific circumstances in terms of measuring the social and economic impact. However, the implementation of this typology in individual non-profit organisations can be challenging because it requires the gathering of resources and expertise from multiple parties to agree on the evaluation criteria that should be employed.

\subsection{Relevance of Assessment Tools to Firm Size}

This study found twelve studies that identified tools relevant to small-, medium- and largesized enterprises, with five relevant to those small and medium sized, and one being relevant to large enterprises, whilst one tool was relevant to small and large enterprises. Interestingly, eight studies did not specify the firm size in their assessment. Although the rationale for 'not specified' was not disclosed, it was noted that the studies did not seek to identify the relevance of the firm size to the assessment tool(s) selected. Therefore, this study contributes to the importance of the firm size when analysing SI. Those studies that identified small-, medium- and large-sized firms (i.e. McLoughlin et al., 2009; Gibbon and Dey, 2011; Maas and Liket, 2011; Clark and Brennan, 2012; Arvidson and Lyon, 2014; Ebrahim and Rangan, 2014; Pathak and Dattani, 2014; Grieco et al., 2015; Migliavacca, 2016; Kato et al., 2017; Belluci et al., 2019) used different methodologies and methods to assess the potency of the tools; for example, Belluci et al. (2019) assessed SROI's effectiveness as an SI tool for nonprofit organisations and SEs that provide family-centred support, finding that SROI can be adopted by any size firm regardless of their social objectives. However, stakeholder participation is crucial to the effectiveness of the information captured and measured. Furthermore, technical expertise is vital to the information captured and analysed using SROI, because large datasets are required for the measurement. Despite the strength of the SROI tool, the required technical expertise poses a greater challenge for small-sized enterprises. 
On the other hand, McLoughlin et al.'s (2009) assessment of the SIMPLE tool demonstrates how SEs scope, map, track, report and embed SI indicators in their organisations. Given that the SIMPLE methodology adopted by the authors was tested on over 40 SEs, the study presents a systematic approach to developing SI baselines for small-, medium- and large-sized firms. Nonetheless, the study presents limitations with regards to how SEs embed best practice for the SIMPLE methodology. To address this weakness, the authors suggested further research to explore the implementation post-training for those organisations that did not facilitate embedding processes in their models. Interestingly, Maas and Likert (2011) empirically tested enterprises' strategic philanthropic activities to identify whether firm size, the philanthropic expenditure, region and industry influence the extent that various dimensions of social good are measured. Unsurprisingly, the authors found that large enterprises in the financial sectors operating in Europe and North America are more likely to measure SI.

Similarly, those studies that identified small- and medium-sized firms adopted both qualitative and quantitative methodologies (i.e. Bagnoli and Megali, 2011; Barraket and Yousefpour, 2013; Hadad and Găucă, 2014; Arena et al., 2015; White, 2018). For example, Barraket and Yousefpour (2013) investigated SI in five small and medium-sized SEs in Australia, where they found that the perceived benefits of measuring impact are organisational learning and performance, even though the dominant driver for measurement is to demonstrate legitimacy to external stakeholders. Nonetheless, small and medium-sized organisations face two main issues: i) impact readiness, which emphasises when SI should be captured; and ii) resourcing, as echoed by White (2018) who examined SI using Sen's (1985, 1987, 1993) capability approach. In contrast, Rawhouser et al.'s (2019) systematic review of SI tools found that the majority were utilised by small- and large-sized organisations. Unlike 
the present study, the authors' review extended beyond the remit of social entrepreneurship, thus limiting the contextual relevance for SE.

\subsection{Framework for Selecting Social Impact Tools}

We set out to develop a framework to enable SEs to select the most appropriate tool for SIM. Following our discussion of the 27 papers reviewed in this study, we created the suitability framework based on those studies that developed models, to ensure empirically tested recommendations. As SEs face accountability and legitimacy challenges (Bradford et al., 2020; Nicholls, 2009) and selection of the most appropriate tool to establish legitimacy (Haski-Leventhal and Mehra (2016), the framework developed in this study address both challenges. More specifically, it provides SEs with the tools to reinforce SIM in their operational plan and share information about the achievement of their social interventions thus establishing legitimacy. Furthermore, using a tool to examine SI could minimise bias in data entry and measurement. The communication of this data is critical for improving SE performance (Nicholls, 2009).

The following ten models guided this framework: the framework for capability and integrative approaches (White, 2018), the performance measurement system model (Arena $e t$ al., 2015), the structural equation modelling of SI (Edwards et al., 2015), the sustainability, added value and scalability (Hadad and Găucă, 2014), the social performance framework (Ebrahim and Rangan, 2014), the analytical framework (Mouchamps, 2014), the multidimensional controlling model (Bagnoli and Megali, 2011), the economic survival framework (Lane and Casile, 2011), the four-category typology of alternative approaches (Polonsky and Grau, 2011), and the blended value accounting spectrum (Nicholls, 2009).

White (2018) developed the framework for capability and integrative approaches, with the model based on a hybrid grounded in Sen's capabilities approach and 
configurational theory to demonstrate integrative approaches for capturing the SI of SEs. As noted in Figure 2, the model captures social contributions from small-, medium- and largesized enterprises. White (2018) argued that social value can be understood through capabilities, that is, how SEs perceive and achieve social value. Therefore, the integrative approach will encapsulate the balance between different components and can be viewed as a balance between positive approaches.

The performance measurement system by Arena et al. (2015) is a framework that enables an SE or external expert to develop their SI system. As noted in Figure 2, the performance measurement system is appropriate for small- and medium-sized SEs with a social, economic or environmental goal. There are six steps to developing an SI system using this framework: i) map the available documents of the organisation (i.e. the social annual reports and company accounts); ii) conduct interviews with different stakeholder (internal and external) groups to capture their needs and comprehend how the social interventions are perceived; iii) identify the performance dimensions most coherent with the organisation's information needs (i.e. financial sustainability, effectiveness, impact, and efficiency) (Arena et al., 2015); iv) construct a performance measurement system through the set of indicators that must be clear and reflective of the social, economic or environmental interventions; v) conduct a review of this process with key stakeholders to collect feedback; and vi) redefine the system based on the information collected.

In contrast, Edwards et al. (2015) proposed the structural equation modelling for SIM, which aims to provide a framework for the development of theory and to empirically test SI systematically. The model captures economic and social contributions, and the environmental impact of large enterprises. The authors argued that SI has a ripple effect from the core central state of belonging to the impact of other factors. Based on this notion, Edwards et al. (2015) made four propositions. First, SI begins within the organisation's sense of belonging. 
Second, social citizenship values are critical to the development of SI, with human capital developing in the form of new skills as people extend their knowledge and experience. Third, SI is accomplished at both the individual and the organisational level. Finally, SI develops from the growth of individual action and organisational programmes.

Like the structural equation modelling, the sustainability, added value and scalability model by Hadad and Găucă (2014) is suitable for small- and medium-size SEs with SEE goals. To implement the model, the organisation should identify all activities and map indicators to the activities. Then, a sustainable timeframe for measurement should be determined: short ( 1 year), medium (3-5 years) and long term ( $7+$ years). The organisation should identify those resources that will support SIM for set time frames, which can include finance, knowledge, human resource and technical. Once resources have been identified, a review of the SEE effects will add value regarding external knowledge on issues that could impact the organisation's measurement standards. Depending on the level of activity, scalability can provide potential for expansion and media coverage of the SI captured, and the indirect effects of the social intervention.

The social performance framework by Ebrahim and Rangan (2014) is appropriate for small-, medium- and large-sized enterprises with SEE contributions. To adopt this framework, organisations should clarify the operational mission, specify the set of activities to address the scope, and identify the target size of the scale. This framework enables organisations to adapt their metrics of scope and scale to their context. Interestingly, Mouchamps's (2014) analytical framework provides organisations with an approach to analysing existing SI frameworks, where the models analysed are classified according to monetary and non-monetary indicators.

The multi-dimensional controlling model (Bagnoli and Megali, 2011) is suitable for small and medium-sized SEs with SEE goals, whereby the framework has three reference 
dimensions of control: economic and financial performance, social effectiveness and institutional legitimacy. Meanwhile, Lane and Casile's (2011) economic survival framework provide SEs with measures for comprehensive performance measurement based on their respective organisational mission through using the survival, action and social change model. However, we found that the economic survival framework does not specify the firm size, although it does identify the SEE contributions.

Like the performance measurement system, Polonsky and Grau (2011) developed a four-category typology of alternative approaches to SIM. This model supports social contributions and environmental impact, but again does not specify the firm size. The categories are divided into two sections: financial, such as operational efficiency and SI approach; and non-financial, such as the qualitative impact of the approach measurement and combination approaches to measurement. The present authors argue that transparency is vital to the evaluation process of SIM. The final framework developed by Nicholls (2009) is blended value accounting, which draws from the work of Emerson (2003). As per the economic survival framework and four-category typology, blended value accounting does not specify what firm size is suitable to adopt the framework, although it is appropriate for organisations with economic and social contributions, and environmental impact. 


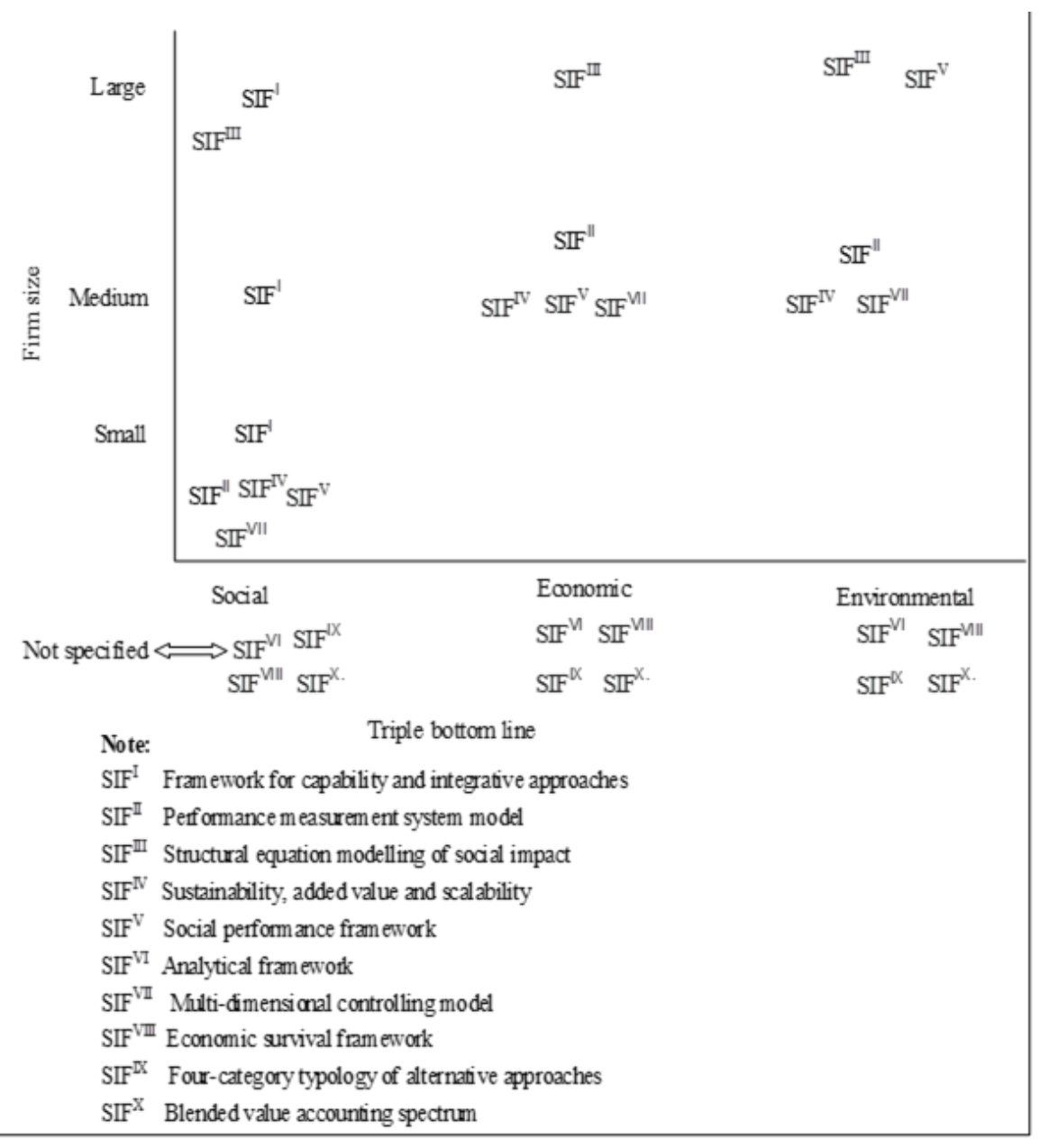

Figure 2. The suitability framework

\section{Conclusions}

Despite the plethora of tools and frameworks, SEs face challenges of what and how to measure, and what information to report. This study reviewed the extant research on SI tools over the past decade, providing a clear view of the state of SI research, and a practical framework for SEs to identify the optimum tool that meets their precise objective. The study targeted some of the top FT50 journals in business management to identify diverse articles both conceptually and empirically in the construct of SI. Careful consideration was given to the selection criteria to ensure representative and relevant articles were identified. We acknowledge that our review may have excluded some articles, given the inconsistent use of the terms associated with SI. Nonetheless, the methodological process was thorough, 
providing clear evidence of the studies on SI and allowing the development of the Suitability Framework for selecting SI tools. However, this review is not exhaustive, as we see opportunities for scholars to extend the sample selection criteria for systemic review and participatory analysis of the suitability framework in real-life SEs. Furthermore, limited research has been undertaken on most of the tools outlined in Table I. Future research could investigate the implementation process, specifically exploring the impact indicators and embedment of SI processes.

In the discussion surrounding SIM, we found that transparency, accountability and legitimacy from external stakeholders are common rationales for measuring SI. It was also established that SEs recognise their social interventions and seek to better understand the impact of these interventions on society. Thus, the three dimensions of legitimacy theory by Suddaby et al. (2016) formed the theoretical lens for this study. This study contributes to legitimacy as a perception since the developed framework will enable SEs to identify the most appropriate tool for their SEE objectives and firm size. The identification of a tool and evaluation (the perception) of SE interventions becomes the communication process for legitimising the organisation. Therefore, this paper uncovers our understanding of some challenges faced by SEs - coercive pressure from external stakeholders to measure SI and identification appropriate tool for SIM. By presenting the suitability framework, a comprehensive analysis of the challenges is presented.

The framework also contributes to the models for SIM in social entrepreneurship, providing an analytical structure for SEs to identify the optimum tool for their social, economic or environmental goals, while taking the firm size into consideration. The initial contribution was the two review dimensions for this study: i) the focus of assessment (i.e. environmental contribution, social contribution and economic impact); and ii) firm size (i.e. 
small, medium and large). This was followed by the framework, developed to enable SEs to select the most appropriate tool to fit their precise needs.

\section{Disclosure}

No potential conflicts of interest.

\section{References}

Acs, Z., Boardman, M., and McNeely, C. (2013), "The social value of productive entrepreneurship", Small Business Economics, vol. 40 no. 3, pp.785-796.

Adams, S. and Simnett, R. (2011), "Integrated reporting: An opportunity for Australia's not for profit sector", Australian Accounting Review, vol. 21 no. 3, pp.292-301.

Arena, M., Azzone, G., and Bengo, I. (2015), "Performance measurement for social enterprises", VOLUNTAS: International Journal of Voluntary Nonprofit Organizations, vol. 26 no. 2, pp.649-672.

Arthur, L., Scott Cato, M., Keenoy, T., and Smith, R. (2003), "Developing an operational definition of the social economy", Journal of Cooperative Studies, vol. 36 no. 3, pp.1-23.

Arvidson, M. and Lyon, F. (2014), "Social impact measurement and non-profit organisations: compliance, resistance, and promotion", VOLUNTAS: International Journal of Voluntary and Nonprofit Organizations, vol. 25 no 4, pp.869-886.

Arvidson, M., Lyon, F., Mackay, S., and Moro, D. (2010), The ambitions and challenges of SROI. Third Sector Research Centre, Working Paper 49, Third Sector Research Centre, University of Birmingham, Birmingham.

Asmalovskij, A., Sadílek, T., Hinčica, V., and Mizerová, M. (2019), "Performance of Social Enterprises in the Czech Republic", Journal of Social Entrepreneurship, vol. 10 no 1, pp.1929.

Azmat, F., Ferdous, A.S., and Couchman, P. (2015), "Understanding the dynamics between social entrepreneurship and inclusive growth in subsistence marketplaces", Journal of Public Policy \& Marketing, vol. 34 no. 2, pp.252-271.

Bagnoli, L. and Megali. C. (2011), "Measuring performance in social enterprises", Nonprofit and Voluntary Sector Quarterly, vol. 40 no 1, pp.149-165. 
Barraket, J., and Yousefpour, N. (2013), "Evaluation and social impact measurement amongst small to medium social enterprises: Process, purpose and value", Australian Journal of Public Administration, vol. 72 no. 4, pp.447-458.

Bellucci, M., Nitti, C., Franchi, S., Testi, E., and Banoli, L. (2019), "Accounting for social return on investment (SROI). The costs and benefits of family-centred care by the Ronald McDonald House Charities", Social Enterprise Journal, vol. 15 no. 1, pp.46-75.

Burdge, R.J. and Vanclay, F. (1996), "Social impact assessment: A contribution to the state of the art series", Impact Assessment, vol. 14 no. 1, pp.59-86.

Cho, Y. and Marshall Egan, T. (2009), "Action learning research: A systematic review and conceptual framework", Human Resource Development Review, vol. 8 no. 4, pp.431-462.

Clark, C. and Brennan, L. (2012), "Entrepreneurship with social value: A conceptual model for performance measurement", Academy of Entrepreneurship Journal, vol. 18 no. 2, pp.17-40.

Clifford, J., Markey, K., and Malpani, N. (2013), Measuring social impact in social enterprises: The state of thought and practice in the UK, E3M, London.

Connolly, C. and Kelly, M. (2011), "Understanding accountability in social enterprise organisations: A framework", Social Enterprise Journal, vol. 7 no 3, pp.224-237.

Cordery, C. and Sinclair, R. (2013), "Measuring performance in the third sector", Qualitative Research in Accounting \& Management, vol. 10 no. 3-4, pp.196-212.

Costa, E. and Pesci, C. (2016), "Social impact measurement: why do stakeholders matter?", Sustainability Accounting, Management and Policy Journal, vol. 7 no. 1, pp.99-124.

Crucke, S. and Decramer, A. (2016), "The development of a measurement instrument for the organizational performance of social enterprises", Sustainability, vol. 8 no. 2, pp.161-190.

Dacin, P.A., Dacin, M.T., and Matear, M. (2010), "Social entrepreneurship: Why we don't need a new theory and how we move forward from here", The Academy of Management Perspectives, vol. 24 no. 3, pp.37-57.

Dart, R. (2004) "The legitimacy of social enterprise", Nonprofit Management and Leadership, vol. 14 no. 4 , pp.411-424.

Datta, P.B. and Gailey, R. (2012), "Empowering women though social entrepreneurship:

Case study of a women's cooperative in India", Entrepreneurship Theory \& Practice, vol. 36 no. 3 , pp.569-587.

Defourny, J. and Nyssens, M. (2008), "Social enterprise in Europe: Recent trends and developments", Social Enterprise Journal, vol. 4 no. 3, pp.202-228.

Department of Health. (2011), Open Public Services, White Paper, The Stationery Office Limited, London.

Department of Trade and Industry. (2002), Social enterprise: A strategy for success, DTI, London. 
Desa, G. and Basu, S. (2013), "Optimization or bricolage? Overcoming resource constraints in global social entrepreneurship", Strategic Entrepreneurship Journal, vol. 7 no. 1, pp.26-49.

Di Domenico, M., Haugh, H., and Tracey, P. (2010), "Social bricolage: Theorizing social value creation in social enterprises", Entrepreneurship Theory and Practice, vol. 34 no. 4, pp.681703.

Doherty, B., Haugh, H., and Lyon, F. (2014), "Social enterprises as hybrid organisations: a review and research agenda", International Journal of Management Reviews, vol. 16 no. 4, pp.417-463.

Ebrahim, A. and Rangan, V.K. (2010), The limits of nonprofit impact: a contingency framework for measuring social performance, Working Paper 10-099, Harvard Business School, Boston, MA.

Ebrahim, A. and Rangan, V.K. (2014), "What impact? A framework for measuring the scale and scope of social performance", California Management Review, vol. 56 no. 3, pp.118-141.

Ebrahim, A., Battilana, J., and Mair, J. (2014), "The governance of social enterprises: Mission drift and accountability challenges in hybrid organizations", Research in Organizational Behavior, vol. 34, 81-100.

Edwards, M., Onyx, J., Maxwell, H., Darcy, S., Bullen, P., and Sherker, S. (2015), "A conceptual model of social impact as active citizenship", VOLUNTAS: International Journal of Voluntary and Nonprofit Organizations, vol. 26 no. 4, pp.1529-1549.

Emerson, J. (2003), "The blended value proposition: Integrating social and financial returns", California Management Review, vol. 45 no. 4, pp.35-51.

Esteves, A.M., Franks, D., and Vanclay, F. (2012), "Social impact assessment: the state of the art", Impact Assessment and Project Appraisal, vol. 30 no. 1, pp.34-42.

Florman, M., Klinger-Vidra, R., and Facada, M. J. (2016), A critical evaluation of social impact assessment methodologies and a call to measure economic and social impact holistically through the External Rate of Return platform, Working Paper 160 (pp.1-32), London School of Economics Enterprise, London.

Folmer, E., Nederveen, C., and Schutjens, V. (2018), "Network importance and use: commercial versus social enterprises", Social Enterprise Journal, vol. 14 no. 4, pp.470-490.

Ghauri, P., Tasavori, M., and Zaefarian, R. (2014), "Internationalisation of service firms through corporate social entrepreneurship and networking", International Marketing Review, vol. 31 no. 6, pp.576-600.

Gibbon, J. and Dey, C. (2011), "Developments in social impact measurement in the third sector: scaling up or dumbing down?", Social and Environmental Accountability Journal, vol. 31 no. 1, pp.63-72.

Gordon, K., Wilson, J., Tonner, A., and Shaw, E. (2018), "How can social enterprises impact health and well-being?", International Journal of Entrepreneurial Behavior \& Research, vol. 24 no. 3, pp.697-713. 
GOV.UK. (2020), "Social impact investment taskforce", available at: https://www.gov.uk/government/groups/social-impact-investment-taskforce (accessed 4 July 2020).

Grieco, C., Michelini, L., and Iasevoli, G. (2015), "Measuring value creation in social enterprises: A cluster analysis of social impact assessment models", Nonprofit and Voluntary Sector Quarterly, vol. 44 no. 6, pp.1173-1193.

Hadad, S. and Găucă, O. (2014), "Social impact measurement in social entrepreneurial organizations", Management \& Marketing. Challenges for the Knowledge Society, vol. 9 no. 2, pp.119-136.

Hall, M. (2014), "Evaluation logics in the third sector", VOLUNTAS: International Journal of Voluntary and Nonprofit Organisations, vol. 25 no. 2, pp.307-336.

Hall, M., Millo, Y., and Barman, E. (2015), "Who and what really counts? Stakeholder prioritization and accounting for social value. Journal of Management Studies, vol. 52 no. 7, pp.907-934.

Haski-Leventhal, D. and Mehra, A. (2016), "Impact measurement in social enterprises: Australia and India", Social Enterprise Journal, vol. 12 no. 1, pp.78-103.

HM Government. (2012), Public Services (Social Value) Act (2012), The Stationary Office, London.

Izzo, D. (2013), "Aligning interesting in impact investing", available at: https://ssir.org/articles/entry/aligning_interests_in_impact_investing (accessed 4 July 2020).

Kato, S., Ashley, S.R., and Weaver, R.L. (2018), "Insights for measuring social value: Classification of measures related to the capabilities approach", VOLUNTAS: International Journal of Voluntary and Nonprofit Organizations, vol. 29 no. 3, pp.558-573.

Lane, M.D. and Casile, M. (2011), "Angels on the head of a pin", Social Enterprise Journal, vol. 7, 238-258.

Luke, B.G. (2016), "Measuring and reporting on social performance: From numbers and narratives to a useful reporting framework for social enterprises", Social and Environmental Accountability Journal, vol. 36 no. 2, pp.103-123.

Luke, B.G., Barraket, J., and Eversole, R. (2013), "Measurement as legitimacy versus legitimacy of measures", Qualitative Research in Accounting \& Management, vol. 10 no. 3-4, pp.234-258.

Maas, K. and Liket, K. (2011), "Social Impact Measurement: Classification of Methods", Burritt, R., Schaltegger, S., Bennett, M., Pohjola, T., and Csutora, M. (Eds.), Environmental Management Accounting and Supply Chain Management: Eco-Efficiency in Industry and Science 27, Springer, Dordrecht.

MacIndoe, H. and Barman, E. (2013), "How organizational stakeholders shape performance measurement in nonprofits: Exploring a multidimensional measure. Nonprofit and Voluntary Sector Quarterly, vol. 42 no. 4, pp.716-738. 
McLoughlin, J., Kaminski, J., Sodagar, B., Khan, S., Harris, R., Arnaudo, G., and McBreaty, S. (2009), "A strategic approach to social impact measurement of social enterprises: The SIMPLE methodology", Social Enterprise Journal, vol. 5 no. 2, pp.154-179.

Migliavacca, A.M. (2016), "Social impact measurement practices: A metaanalysis", International Journal Series in Multidisciplinary Research, vol. 2 no. 3, pp.1-17.

Mouchamps, H. (2014), "Weighing elephants with kitchen scales: The relevance of traditional performance measurement tools for social enterprises", International Journal of Productivity and Performance Management, vol. 63 no. 6, pp.727-745.

Murphy, P.J. and Coombes, S.M. (2009), A model of social entrepreneurial discovery. Journal of Business Ethics, vol. 87 no. 3, pp.325-336.

New Economics Foundation. (2009), Tools for you: approaches to proving and improving for charities, voluntary organisations and social enterprise, New Economics Foundation Consulting, London.

Nicholls, A. (2008), "Capturing the performance of the socially entrepreneurial organisation (SEO): An organisational legitimacy approach”. In J. Robinson, J. Mair \& K. Hockerts (Eds.), International perspectives on social entrepreneurship research: 27-74. London: Palgrave Macmillan.

Nicholls, A. (2009), "We do good things, don't we?: 'Blended value accounting', social entrepreneurship", Accounting, Organizations and Society, vol. 34 no. 6-7, pp.755-769.

Nicholls, A. (2010), "The legitimacy of social entrepreneurship: reflexive isomorphism in a pre-paradigmatic field", Entrepreneurship Theory and Practice, vol. 34 no. 4, pp.611-633.

Nicolopoulou, K. (2014), "Social entrepreneurship between cross-currents: Toward a framework for theoretical restructuring of the field", Journal of Small Business Management, vol. 52 no. 4 , pp.678-702.

Nolan, C.T. and Garavan, T.N. (2016), "Human resource development in SMEs: A systematic review of the literature", International Journal Management Review, vol. 18 no. 1, pp.85-107.

OECD. (2004), "Promoting entrepreneurship and innovative SMEs in a global economy:

Towards a more responsible and inclusie globalisation", available at:

https://www.oecd.org/cfe/smes/31919294.pdf (accessed 5 July 2020).

OECD. (2015), "Social impact investment", available at: http://www.oecd.org/sti/ind/socialimpact-investment.htm (accessed 2 July 2020).

OECD. (2020), "Enterprises by business size (indicator)", available at: 10.1787/31d5eeaf-en (accessed 5 July 2020)

Organisation for Economic and Development. (2010), "Policy brief on social impact measurement for social enterprises", available at: https://www.oecd.org/social/PB-SIMWeb_FINAL.pdf (accessed 30 January 2019). 
Pathak, P. and Dattani, P. (2014), "Social return on investment: three technical challenges", Social Enterprise Journal, vol. 10 no. 2, pp.91-104.

Paterson-Young C., Hazenberg R., Bajwa-Patel M. (2019), "Social impact measurement and youth justice. In: The social impact of custody on young people in the criminal justice system. Palgrave Macmillan, Cham.

Patten, D.M. (1992) "Intra-industry environmental disclosures in response to the Alaskan oil spill: A note on legitimacy theory", Accounting, Organizations and Society, vol. 17 no. 5, pp.471-475.

Phillips, W., Lee, H., Ghobadian, A., O’Regan, N., and James, P. (2015), "Social innovation and social entrepreneurship: A Systematic Review", Group \& Organization Management, 134.

Polonsky, M. and Grau, S.L. (2011), "Assessing the social impact of charitable organizationsfour alternative approaches", International Journal of Nonprofit and Voluntary Sector Marketing, vol. 16 no. 2, pp.195-211.

Pritchard, D., Ogain, E., and Lumley, T. (2012), Making an impact: Impact measurement among charities and social enterprises in the UK, New Philanthropy Capital, London.

United Nations Development Programme and Global Reporting Initiative. (2016), "Measuring impact: How business accelerate the sustainable development goals", available at: https://www.globalreporting.org/resourcelibrary/Meassuring\%20Impact_BCtA_GRI.pdf (accessed 3 July 2020).

Rawhouser, H., Cummings, M., and Newbert, S.L. (2019), "Social Impact Measurement: Current Approaches and Future Directions for Social Entrepreneurship Research", Entrepreneurship Theory and Practice, vol. 43 no. 1, pp.82-115.

Ridley-Duff, R. and Southcombe, C. (2012), "The social enterprise mark: A critical review of its conceptual dimensions", Social Enterprise Journal, vol. 8 no. 3, pp.178-200.

Ruebottom, T. (2011), "Counting social change: outcome measures for social enterprise", Social Enterprise Journal, vol. 7 no. 2, pp.172-182.

Salazar, J., Husted, B.W., and Biehl, M. (2012), "Thoughts on the evaluation of corporate social performance through projects", Journal of Business Ethics, vol. 105 no. 2, pp.175-186.

Santos, F. (2012), "A positive theory of social entrepreneurship", Journal of Business Ethics, Vol. 111 no. 3, pp. 335-351.

Sen, A.K. (1985), Commodities and Capabilities, Elsevier Science Publishers, Oxford.

Sen, A.K. (1987), The standard of living: The tanner lectures, Cambridge University Press, Cambridge.

Sen, A.K. (1993), "Capability and well-being", Nussbaum, M.C. and Sen, A.K. (Eds.), The Quality of Life (pp.30-53), Clarendon Press, Oxford. 
Shocker, A.D. and Sethi, S.P. (1974), "An approach to incorporating social preferences in developing corporate action strategies", Sethi, S.P (Ed.), The Unstable Ground: Corporate Social Policy in a Dynamic Society, Melville Publishing Company, Los Angeles, CA.

Siqueira, A.C.O., Guenster, N., Vanacker, T. and Crucke, S. (2018), "A longitudinal comparison of capital structure between young for-profit social and commercial enterprises, Journal of Business Venturing, vol. 33 no 2, pp.225-240.

Social Enterprise UK. (2017), "The future of business: State of social enterprise survey 2017", Favailable at:

https://www.socialenterprise.org.uk/Handlers/Download.ashx?IDMF=a1051b2c-21a4-461a896c-aca6701cc441 (accessed 11 January 2019).

Social Impact Investment Taskforce. (2012), "Measuring impact", available at http://www.siiq.com.au/uploads/2/4/8/5/24851283/imwg_whitepaper.pdf (accessed 7 July 2020).

Spear, R., Cornforth, C., and Aiken, M. (2009), "The governance challenges of social enterprises: Evidence from a UK empirical study", Annals of Public and Cooperative Economics, vol. 80 no. 2, pp.247-273.

Steinerowski, A. and Steinerowska-Streb, I. (2012), "Can social enterprise contribute to creating sustainable rural communities? Using the lens of structuration theory to analyse the emergence of rural social enterprise. Local Economy, vol. 27 no. 2, pp.167-182.

Suchman, E.A. (1967), "Evaluative research: Principles and practice in public service and social action programs". New York: Russell Sage Foundation.

Suchman, M.C. (1995), "Managing legitimacy: Strategic and institutional approaches", Academy of Management Review, vol. 20 no. 3, pp.571-610.

Suddaby, R., Bitektine, A., and Haack, P. (2016), "Legitimacy", Academy of Management Annals, vol. 11 no. 1, pp.451-478.

Syrjä, P., Sjögrén, H., and Ilmarinen, A. (2015), "Performance measurement in social enterprises - a conceptual accounting approach", in 5th EMES International Research Conference on Social Enterprise - Building a scientific field to foster the social enterprise ecosystem, pp.1-14.

Wainwright, S. (2002), Measuring impact: A guide to resources, NCVO Publications, London.

Weiss, C. (1995). "Nothing as practical as good theory: Exploring theory-based evaluation for comprehensive community initiatives for children and families', in J. P. Connell, A. C. Kubisch, L. B. Schorr and C. H. Weiss (eds) New Approaches to Evaluating Community Initiatives: Volume 1, Concepts, Methods, and Contexts. Washington, DC: The Aspen Institute

White, L. (2018), “A Cook's Tour: Towards a framework for measuring the social impact of social purpose organisations". European Journal of Operational Research, vol. 268 no. 3, pp.784-797. 
World Health Organisation. (2017) " 2.1 billion people lack safe drinking water at home, more than twice as many lack safe sanitation", available at: https://www.who.int/newsroom/detail/12-07-2017-2-1-billion-people-lack-safe-drinking-water-at-home-more-thantwice-as-many-lack-safe-sanitation (accessed 20 December 2018).

Zahra, S.A., Gedajlovic, E., Neubaum, D.O., and Shulman, J.M. (2009), "A typology of social entrepreneurs: Motives, search processes and ethical challenges", Journal of Business Venturing, vol. 24 no. 5, pp.519-532.

Zappalà, G. and Lyons, M. (2009), "Recent approaches to measuring social impact in the Third sector: An overview", The Centre for Social Impact, CSI Background Paper 6, available at: https://www.socialauditnetwork.org.uk/files/8913/2938/6375/CSI_Background_Paper_No_5 _-_Approaches_to_measuring_social_impact_-_150210.pdf (accessed 13 November 2018). 